TITLE:

\title{
Generation of human oogonia from induced pluripotent stem cells in vitro(Abstract_要旨 )
}

\author{
$\operatorname{AUTHOR}(\mathrm{S})$ : \\ Yamashiro, Chika
}

\section{CITATION:}

Yamashiro, Chika. Generation of human oogonia from induced pluripotent stem cells in vitro. 京都大学, 2019, 博士(医学)

ISSUE DATE:

2019-03-25

URL:

https://doi.org/10.14989/doctor.k21663

RIGHT: 


\begin{tabular}{|c|c|c|c|}
\hline 京都大学 & 博士 (医 学 ) & 氏 名 & 山城 知佳 \\
\hline 論文題目 & $\begin{array}{l}\text { Generation of human oogonia from induced pluripotent stem cells in vitro } \\
\text { (ヒト iPS 細胞を由来とする卵原細胞の試験管内誘導) }\end{array}$ \\
\hline
\end{tabular}

(論文内容の要旨)

生殖細胞は, 新たな個体を創出し, 遺伝情報を次世代一と継承することに特 化した唯一の細胞系譜である. 多能性幹細胞から生殖細胞への分化誘導は，不 妊治療への応用のみならず，生命の連続性を保障する分子基盤を理解するうえ で有用な研究分野である。これまでに, マウス多能性幹細胞から始原生殖細胞 様細胞（Primordial Germ Cell-like Cells： PGCLCs）を培養下で誘導し，正常 な産仔能をもつ精子や卵子へと分化させる技術が開発されてきた。一方でヒト 多能性幹細胞を起点とした分化誘導については，ヒト人工多能性幹 (induced Pluripotent Stem：iPS）細胞から PGCLCs を誘導することには成功していた ものの，その後の発生・分化過程は再現できずにいた。そこで本研究では，ヒ 卜PGCLCs を卵原細胞, さらには卵母細胞へ分化させることを目標に検討を試 みた。

始原生殖細胞が雌性生殖細胞として分化する環境を模倣するために，ヒト iPS 細胞から誘導したヒト PGCLCs を胎齢 12.5 日のマウス雌性生殖巣体細胞 と凝集させ（異種間再構成卵巣），コラーゲンをコートしたナイロン膜上で培 養した，培養 77 日を経過した PGCLC 由来細胞では，DDX4 を含む卵原細胞 への分化を示すマーカータンパク質の発現がみとめられ，透過型電子顕微鏡に よる観察においても卵原細胞の形態学的特徵をよく示していた。これらの PGCLC 由来卵原細胞について網羅的遺伝子発現解析を行ったところ, 卵原細 胞以降の生殖細胞特異的な遺伝子群の発現が顕著に上昇していた一方で，体細 胞への分化に関連する遺伝子群の発現は低下していた。さらに，培養 120 日を 経過した PGCLC 由来細胞のうち DDX4 を強発現した一部の細胞群では, 減数 分裂の前段階である “レチノイン酸応答性” 卵原細胞に相当する遺伝子発現を 示していた。すなわちこれらの細胞群では, 卵母細胞へと分化する直前まで発 生が進行していることが示唆された。

また, 卵原細胞への分化過程で起こるエピゲノムリプログラミングが PGCLC 由来卵原細胞においても進行しているかどうかを検証するために，全 ゲノム DNA メチル化解析を行った。その結果, PGCLC 由来卵原細胞では, 多 能性幹細胞における異常メチル化およびインプリント情報の消去を含む，大規 模な DNA 脱メチル化が引き起こされていた。加えて, 初期胚において不活性 化された X 染色体では，DNA 脱メチル化に伴う部分的な再活性化がみとめら れた.

培養 77 日から 120 日を経た PGCLC 由来卵原細胞をヒト胎児生殖細胞と比

較したところ，遺伝子発現・DNA メチル化状態ともに，発生約 7 10 週（妊娠 9 12 週）頃の卵原細胞に酷似していた.

以上，本研究はヒト iPS 細胞から誘導した PGCLCs を卵原細胞へと分化さ せる技術を開発し，また，ヒトPGCLCs が生殖系列細胞として分化する能力を 有すことを証明したものである. 本成果はヒト始原生殖細胞から配偶子 (卵子) 一分化寸る過程の初期段階の解析を可能にし，将来的には卵子における遺伝情 報継承機構の追究や，不妊症の原因究明および遺伝病の発症機構解明に寄与寸 ることが期待される。

\section{(論文審査の結果の要旨)}

多能性幹細胞から生殖細胞を分化させる体外培養系の確立は、次世代一の遺 伝情報継承機構の解明を可能とし、発生生物学や生殖医学の発展に寄与する。 これまで、マウス多能性幹細胞から機能的な精子および卵子への分化誘導が報 告されてきたが、ヒト多能性幹細胞を起点とした検討においては、iPS 細胞か ら始原生殖細胞様細胞（Primordial Germ Cell-like Cells: PGCLCs）への誘導 にとどまっていた。

本研究では、ヒトiPS 細胞から誘導した PGCLCs をマウス胎仔卵巣体細胞と 凝集させ（異種間再構成卵巣）、気液平衡条件にて最大 120 日間培養すること により、卵原細胞へと分化させる系を構築した。得られたiPS 細胞由来卵原細 胞は、ヒト胎児卵原細胞に特徵的な形態、遺伝子発現、インプリントの消去を 含むゲノムワイドな DNA 脱メチル化、さらに部分的な X 染色体の再活性化を 示した。また培養 120 日を経過したiPS 細胞由来卵原細胞の一部は、減数分裂 への移行期まで分化成熟した。

以上の研究は、ヒ卜始原生殖細胞から卵原細胞への分化過程を試験管内で再 構成する系を提示し、ヒトにおける生殖細胞分化機構の解明に寄与寸るところ が多い。

したがって、本論文は博士（医学）の学位論文として価值あるものと認める。 なお本学位授与申請者は、平成 31 年 2 月 6 日実施の論文内容とそれに関連 した試問を受け、合格と認められたものである。 